\title{
Pandemic Populism: COVID-19 and the Rise of the Nationalist AUR Party in Romania
}

\author{
Claudia Doiciar ${ }^{\mathrm{A}}$, Remus Crețan $\mathrm{A}^{*}$ \\ Received: September 02, 2021 | Revised: November 20, 2021 | Accepted: November 22, 2021 \\ doi: $10.5937 / g p 25-33782$
}

\begin{abstract}
Many Central and Eastern European countries elected nationalist parties after the collapse of communism: a phenomenon often attributed to a combination of socioeconomic crisis and political instability. In 2010s, after the decay of other nationalist parties, Romania was seen as an exception to this rule, but the Covid-19 pandemic times have witnessed the rapid rise of a new nationalist party: the AUR (the Alliance for the Union of Romanians). Parliamentary elections in December 2020 saw this new political force gain $9.1 \%$ of the vote. Whereas previous nationalist parties in post-communist Romania tended to appeal to more senior/elderly voters, there is evidence that the AUR vote is strong amongst men under the age of 35 who are educated to an elementary or high school level. This paper uses national electoral data, media analysis, and in-depth interviews with young, educated people to explore the spatial distribution of AUR support, the ways in which the COVID-19 pandemic has assisted the party's rise to prominence, and attitudes amongst university students to both the style and content of their politics. The paper concludes that the AUR offer a potent mix of old nationalism, religious faith, traditional family values and new ideological elements, such as environmentalism, anti-globalization, and antigovernment critique to create a self-consciously 'alternative' political rhetoric. This is presented via new channels (especially social media) in a deliberately opportunistic, controversial, and spectacular manner. However, our investigation suggests that neither the content nor the style of this politics has widespread appeal among the more educated younger participants to the interview.
\end{abstract}

Keywords: populism; COVID-19; nationalism; AUR; political party; Romania

\section{Introduction}

Many Central and Eastern European countries elected nationalist parties after the collapse of communism: a phenomenon often attributed to a combination of socioeconomic crisis and political instability. Until recently, Romania was seen as an exception to this rule. Though far-right populist movements had a presence in the country, often campaigning against marginalized social groups such as Roma people, LGBT individuals, Jews, and Hungarians, they have not gainedparliamentary power. On the other hand, electoral data suggest that following the death of Vadim Tudor, the leader of the nationalist party Partidul România
Mare (Greater Romania Party) in 2018, many of his political followers shifted their vote to more mainstream parties (BEC, 2020).

However, recent months have witnessed the rapid rise to power of a new nationalist party: the AUR (the Alliance for the Union of Romanians), established in September 2019. Parliamentary elections in December 2020 saw this new political force gain $9.1 \%$ of the vote (541,938 total votes for the Senate, $9.17 \%$ of the total; 535,831 votes for the House of Deputies, $9.08 \%$ of the totals, which equates to 14 senators and 33 deputies). Turnout for this election was $33.3 \%$, the lowest figure

\footnotetext{
A Department of Geography, West University of Timișoara, Vasile Pârvan no 4, 300233 Timișoara, Romania; claudia.doiciar@e-uvt.ro; remus.cretan@e-uvt.ro

* Corresponding author: Remus Crețan; e-mail: remus.cretan@e-uvt.ro
} 
of the post-communist era, in part due to intensifying pandemic restrictions in response to the "second wave" of coronavirus infections. The AUR's success was partly due to reductions in the number of older people voting during the pandemic: the demographics of the party suggest that around $40 \%$ of their supporters are aged under 35 , though only $8 \%$ of the total voters for AUR are university educated. However, during the last two years, the AUR have successfully capitalized on a series of political crises, including rising food, electricity, gas, and petrol prices and the recent collapse of the coalition government between the conservative PNL (National Liberal) party and the reformist and economically liberal USR (Save Romania Union). As a consequence, at the time of writing (October 2021) the AUR are polling around 15\% (Pîrvu, 2021), though support for the left wing Social Democrat Party (PSD) has also increased.

There is some evidence that the COVID-19 pandemic has had particular influence over the rise of the AUR. The pandemic has intensified trends towards growing mistrust of the 'mainstream' political class, and growing trust in religious leaders, not least because the Coalition government has conspicuously mismanaged public health during the outbreak. In the summer of 2021, the Coalition lifted all public health restrictions, despite the fact that Romania had one of the lowest COVID-19 vaccination rates in Europe (under $40 \%$ of the population are fully vaccinated). The rapid spread of the Delta variant consequently led to a lethal fourth wave of coronavirus, peaking at around 500 deaths a day in October 2021. As a result, restrictions have had to be reintroduced, including mask wearing in public places. These, and the government's suggestion that a "vaccine passport" might be necessary to access public places, have been stringently opposed by AUR members, who have organ- ized protests in response. Romanian media suggests that many of those actively protesting against vaccination in Romania are supporters of AUR.

Much recent work has focused on the rise of populism as offering a conspicuously different alternative to established democratic politics (Gherghina et al., 2013; Kriesi, 2014), often using new tools, such as social media, and a very different rhetorical style (Bos et al., 2013; Carter, 2005; Ignazi, 2003; Mudde, 2004; Taggart, 2000;). In this paper, we will focus particularly on the ways in which the visibility of state power during the pandemic, with the enactment of lockdowns, mask wearing, and vaccination programs, has proven fertile ground for populist movements in Romania. The AUR has campaigned against such measures, developing a counter-rhetoric that has linked pandemic measures with more profound themes such as fatherland, family, and religiosity.

This paper will explore the recent rise of the AUR, with a view to reflecting on the different strands of recent political disquiet that have contributed to the rise of populism in Romania. Findings have wider applicability to the rise of nationalism and populism in East-Central Europe in particular (adding to the work of Gherghina \& Miscoiu, 2014; Orenstein \& Bugaric, 2020; Pirro, 2015) and across Europe and other parts of the world (Albertazzi \& McDonnell, 2008; Brubaker, 2017; Brubaker, 2020a; Brubaker, 2020b; de Cleen \& Stavrakakis, 2017; Taggart, 2000). The study aims:

a) to understand the spatial distribution of votes for AUR in Romania

b) and to explore the ways in which the COVID-19 pandemic has created conditions that are conducive to the AUR's success in certain regions

c) to assess responses of the educated younger Romanians to the content and style of the AUR's political ideology

\section{Populism, nationalism and COVID-19 in Central and Eastern Europe}

An explosion of interest in populism following Laclau's (2005) seminal work on the subject has led to criticism of the term's vagueness and overuse. Part of the problem is that populism not only takes many different forms in nationalist identity-based parties across the world (Betz, 2002), but haunts the failures of traditional politics in a variety of different ways (Kriesi, 2014). As Stroschein (2019) has argued, understanding this new politics requires a study of both the forms by which such parties enter and navigate electoral and party systems and the content of their rhetorical appeals to public. In this paper we redeploy this to explore the intertwined content and style of AUR politics, arguing that a deliberately opposition- al challenge to contemporary ways of doing politics in the pandemic context of highly visible government exertions of power is central to their recent success.

Commentators disagree on whether populism operates a troublingly simplistic politics of virtue, or acts as an emancipatory social force through which marginalized groups challenge dominant power groups and structures (Laclau, 2005). Mudde \& Kaltwasser (2013) contend that there are exclusionary and inclusionary varieties of populism, with different configurations succeeding or failing with the public in different places (Carter, 2005; Ignazi, 2003). We seek to explain that both things are simultaneously true: the rise of the AUR is grounded in the opportunity of- 
fered by the pandemic to mount a strong challenge to dominant liberal capitalist ideologies and the exertion of government power, but that this tends to be grounded in an exclusionary and xenophobic nationalist politics. The strangeness of populism, we contend, is that it is often quite prescient in its recognition of the symptoms of contemporary problems (e.g. the effects of rampant capitalism, closed liberal-political structures that simply allow the reproduction of the status quo), yet the racist, xenophobic, and conspiracy-laden misdiagnoses that it subsequently offers divert attention away from real to imagined grievances (Chapman, 2021).

The relationship between populism and nationalism is complex. De Cleen and Stavrakakis (2017) argue for a conceptual distinction between populism and nationalism: in their vision, populist discourse stands on a vertical axis and pictures the people are underdog against an elite, whereas nationalist discourse works on a horizontal axis, and conceptualizes the people as nation. This idea has been criticized by Roger Brubaker (2020a) who argues that it is precisely the productive ambiguity of populist appeals to 'the people', and their ability to mix a critique of elites with an opposition to those who are outside of the nation, that gives them power. In his view, populism is successful because it can slide between definitions of the enemy as both above the people (an analysis centring on inequality within the system) and adjacent to them (an analysis centred on a rejection of difference). Brubaker's combined view helps to explain the ways in which populism counters liberalism with the claim that is a theatre for elite corruption that is also unpatriotic and undermining to national interests.

In Central-Eastern Europe, the 2008 financial crisis combined with shifts in the relationships between individual states and the European Union has given this rhetoric considerable power. In Poland, Hungary, and Serbia, the perceived failure of the neoliberal consensus has led to an intensified form of economic nationalism, which emphasizes sovereignty (often a conservative statism), natalism, and workforce activation (Orenstein \& Bugaric, 2020).

The COVID-19 pandemic has arguably strengthened opposition to neoliberal economics and politics, as disease control measures have increased health, spatial, and socioeconomic forms of inequality. Low-skilled workers and poorer groups, have been disproportionately affected (Mocanu, 2021), particularly those working in agriculture, (traditional and modernized) industries, and tourism (Lucheș et al., 2021; Matei et al, 2021; Popa et al., 2021). Rising unemployment and the imposition of public health measures have accentuated feelings of resentment against the government. COVID-19 has acted as a framework for the rise of AUR, by making government exertions of power unusually visible thus dialectically creating a space for the vigorous assertion of populist opposition.

\section{The AUR, social media, and the 2020 Romanian Parliamentary elections}

Like many other populist organizations, the AUR are highly active on the internet, and especially on social media, using Facebook, TikTok and Instagram. Despa \& Albu (2021) argue that AUR create a series of 'echo-chambers' for the propagation of their views. In these online environments, internet users rarely encounter opinions that contradict their own viewpoint or assumptions, so that existing views are continually reinforced. However, the "echo chamber" metaphor requires qualification, because it tends to assume that limited contact with opposing viewpoints is at the heart of the problem. In fact, populist parties often emphasize the fact that they offer an anti-establishment and oppositional alternative, creating the impression that they are opening a political and discursive space outside of the 'mainstream'. Populism is reactively constructed against established truths: the ability of its adherents to accept an alternative viewpoint (sometimes involving conspiracy theories) is constructed as the hallmark of a "free thinking" individual who has liberated themselves from the dominant ideological blindness.
On their official homepage (Partidul AUR, 2021a), the AUR is presented as the sole opposition party in Romania. Their main political objective is described as the unification of Romania and Moldova, though there is a heavy emphasis on Christian faith, nation, freedom, and traditional family values (homosexuality and same sex marriages are strongly condemned). For instance, in what Voiculescu and Groza (2021) presented as the five spatial articulation of attitudes (the politically conformant, the tolerant, the homophobic, the homosexual, and the passive rural) towards the LGBT families in Romania, AUR members would clearly identify with the homophobic attitude.

The party's opposition to the neoliberal consensus is outlined, with actions against the Hungarian minority living in Transylvania, and protests against political corruption. Objections to pandemic restrictions figure prominently: the individuals responsible for national quarantine, reduced opening hours, school closures, and face-masking are relentlessly criticized, in particular the former Health Minister, Vlad Voiculescu, and the head of the Public 
Health Service, Raed Arafat (Partidul AUR, 2021b). The AUR argues that the system of fines for breaking the state of emergency imposed in 2020-2021 was unconstitutional (Partidul AUR, 2021c), and the party organized a major protest in Bucharest on 13 April 2021 against poor management of public health during the pandemic.

The Facebook page of AUR leader George Simion is highly active: thousands of followers immediately share any post he makes. Messages are simply worded, and present issues in black-and-white terms: all mainstream politicians are corrupt, the values of the Christian family are under threat, Romania is being used as a rubbish heap with garbage imported from other European countries, and so on. The communication style makes heavy use of slogans that present both liberal policies and links to other countries as a weakening influence: "Romania exports cheap wheat and imports poor quality frozen bread that is 13 times more expensive", "Romania imports $70 \%$ of the food it consumes", "the Government jeopardizes the health of the population by closing gyms and sports places" etc. (Simion, 2021). The AUR are quick to capitalize on accidents and tragedies, which they blame on the policies of the European Union: Simion blamed the brutal murder of a Romanian driver by illegal immigrants in France during May 2021 on a lack of protection for such workers from the Romanian Foreign Ministry and the European Union.

As this might suggest, the party are strongly against globalization, using the pandemic as an illustration of the ways in which the sovereign nation is weakened and made vulnerable by international connections. The party presents a view of the future as dominated by strong, national economies that are able to provide all of the goods and services required by their population. For example, they insist on the development of a 'national vaccine' by the Romanian pharmaceutical industry, and especially the Cantacuzino National Institute of Research in Bucharest (Rădulescu, 2021). Sometimes AUR activism can appear oddly contradictory in its logic: the party has campaigned against the involvement of a Canadian company in the Roșia Montană mine on anti-globalization grounds, yet has argued for the inclusion of the site in the UNESCO's World Heritage patrimony (Curierul Național, 2020). However, this combination has proven attractive both to those who are against gold exploitation in the area, and to vulnerable groups confronted with rural decline and unemployment as a result of mono-industrialism (Vesalon \& Crețan, 2013; Rîșteiu et al., 2021). Xenophobia, anti-globalization, nostalgic conservation of the past, and an apparent concern for the marginalized are thus woven together in a politics that appeals to multiple demographics.
Yet, despite the insularity of populist rhetoric, there is some limited evidence of foreign influence over populist policy. While direct proof is lacking, a recent investigation by the Balkan Investigative Reporting Network in Bucharest suggests that there is a significant overlap between AUR rhetoric and policy and that of the Russian Federation (Despa \& Albu, 2021). Social media is a particular focus for these concerns, with AUR-associated Facebook sites promoting the view that corrupt Western influences are responsible for the plunder of Romanian resources and the decline of traditional values. For example, a recent controversy over sex education in schools led the AUR to defend 'traditional' family values via an onslaught against 'gay propaganda' in schools. Their rhetoric closely echoed that which accompanied the passage of a 2013 law in Russia, which banned the "promotion of non-traditional sexual relations to minors". Further, Viktor Orban's Hungarian government promoted similar legislation in mid-2021, banning the depiction of homosexuality to people under 18 years of age (see Despa \& Albu, 2021).

The success of AUR in 2020 Romanian Parliamentary elections came as a shock to both the wider Romanian population and to political analysts and journalists. The surprise was not simply that the party had gained seats, but that it had managed to poll around $9 \%$ of the vote. The reasons for their success are complex. Turnout was exceptionally low at 33.3 , due in part to pandemic restrictions, but also to the fact that many pro-European liberals did not vote, apparently because they were unconvinced by the established parties appealing to their demographic (the Liberal Party, The Social Democrat Party, the USR-Plus Alliance). Another factor was the fact that many younger conservative-leaning or undecided voters who did cast a ballot were not particularly familiar with AUR policies, but felt abandoned by traditional parties and a ruling Coalition dominated by internal struggles for power (Badea, 2020). COVID-19 constitutes an important context across the political spectrum: the government compounded a slow and incoherent response with an emphasis on the needs of big business, which left small to medium enterprises and ordinary people feeling alienated. The failure by any of the established parties to communicate the need for pandemic restrictions in a clear and empathetic way led to a general perception of incompetent and self-interested leadership, and rising distrust. Recognizing this, in the wake of their electoral success, the AUR declared themselves the most important anti-establishment party on the current Romanian political scene.

Since the election result, AUR's success in recruiting well-known and highly recognizable personalities to its cause has led to something approaching a 
"celebrity political war". Writers, philosophers, university professors, and other men and women with a high cultural profile have rallied to the cause of the far right, igniting opposition by a phalanx of similarly influential cultural figures in defence of liberal democratic values In early 2021, the latter created a petition to the leaders of the governing coalition (PNL, PSD, UDMR, USR) asking them not to collaborate with the AUR in any way. They criticize the party's "extremist, toxic ideological mix" in the name of "Euro-Atlantic values", focusing particularly on AUR's "fundamentalist, nationalist, and conspiratorial themes" that are "anti-globalist and anti-individualist" in nature (Gava, 2021; Voicu, 2021). Their argument is that any political party that vehemently opposes the institutions of liberal democracy should not be normalized and legitimated via participation in either dialogue or government. The AUR responded by declaring such actions to be themselves undemocratic: they argue that their policies represent the views of $10 \%$ of 'ordinary Romanians', who would feel disenfranchised by such an act of exclusion (Gava, 2021). The major parties failed to respond to the petition, because it was too politically difficult, so they ignored it.

AUR also deploys the internet to stage spectacular, sometimes, violent 'events', which are livestreamed to their followers. In June 2019, local authorities in Valea Uzului, closed a military cemetery, preventing access to the graves of World War II soldiers of several nationalities. Led by politicians from the Democratic Alliance of the Hungarians in Romania (UDMR), who represent the Hungarian minority in the area, ethnic Hungarians were placed on guard. In response, AUR leader George Simion joined with the New Right movement and a Christian orthodox organization to organize protests. Those attending dressed in traditional folk costumes or as Dacians (the ancient ancestors of Romanians), presenting themselves as the champions of ethnic Romanians, and insisting on their right of entry. Behind this sits a narrative propagated by the AUR that ethnic Romanians living in majority Hungarian areas (like Harghita and Covasna counties) have been abandoned by the government, and left at the mercy of political leadership from the UDMR. Neither the Hungarian minority not its political leadership are represented as being 'properly' loyal to the Romanian state (Partidul AUR, 2021d; Partidul AUR, 2021e). The event ended in violent clashes between the protesters and the local population, and a diplomatic standoff between the foreign offices of Romania and Hungary, with Kelemen Hunor, leader of the UDMR demanded the resignation of both the Foreign Minister and the Minister of Internal Affairs.

Similarly, the government's decision to suspend the traditional pilgrimage and procession to celebrate Saint Parascheva, the patron saint of Moldova, in the autumn of 2020 restrictions proved fertile ground for the AUR. This is the most important pilgrimage in the Romanian Orthodox church, and attracts thousands of people from all over the eastern part of the country, but COVID-19 led to significant restriction of its usual scale: only residents were allowed to participate. Bitter popular resentment, compounded by discontent from members of the Orthodox Church (Popescu, 2020) fuels a narrative propagated by the AUR. AUR members exploited this case by presenting pandemic restrictions as an assault on religious freedom and the 'right to pray'.

\section{Methodology and data}

This paper uses a mixed methods approach to explore the spatial distribution of votes for the AUR in Romania, and to suggest reasons for its success in certain regions and to assess the attitudes of educated younger Romanians to AUR's populist rhetoric. It brings together primary statistical election data, secondary online data (journalism), and in-depth, semi-structured interviews conducted in summer 2021. The election data derives from the Biroul Electoral Central (Romanian Electoral Bureau), and provides an insight in the spatial location of AUR voters, allowing us to compare rural and urban voters in the aggregate, and to explore nationalist support in different regions and local counties within Romania. The secondary data explores the representation of Romanian politics in the mainstream press, based on an internet search using the following keywords: AUR, Romania, national- ism and populism. We selected five critical sources on AUR to explore how they represented the party's policies, using thematic and discursive analysis to identify major themes. Three were drawn from national online journal platforms (Ziare.com, Hotnews, and Agerpress) and two from smaller dedicated news platforms (DC News and PS News, plus a well-known blog by journalist Cristoiu Ioan). We also used the official webpage of Partidul AUR to explore the party's ideology and activism (Partidul AUR, 2021 a, b, c, d, e).

COVID-19 restrictions forced us to adopt Meho's (2006) technique of conducting (semi-structured) interviews by email in order to collect data on the attitudes of educated younger Romanians towards the AUR. Between 6 June and 1 August 2021, we emailed 60 students from the West University of Timisoara (WUT) but only 15 agreed to participate (7 male and 8 
females, most of them residents in western part of Romania) (Table 1). This is a typical number of participants in e-mail interviewing. Range of participants in email interviewing can be from 10 to 60 participants, in comparison to face-to-face interviewing which usually ranges from 5 to about 10 or 15 participants (Meho, 2006, p. 1287). We believe the pandemic was a significant factor in reducing people's availability to engage with online interviews, but the responses we elicited supplied rich information. As Meho (2006) argues, 'semi-structured e-mail interviewing can be a viable al- previous knowledge about the AUR party because they have followed political geography and other human geography courses. There were 19 open-ended questions and 8 closed questions, probing knowledge and feelings about AUR. Interviews took 30-45 minutes to complete, with responses returned between 1 week and 2 weeks from the date of sending. All respondents signed a consent sheet and were diligently informed about the ethics of the interview process. We obtained permission to use name abbreviations and county of residence in publications (Table 1). There were no clear-cut cleav-

Table 1. Socio-demographic characteristics of respondents.

\begin{tabular}{|c|c|c|l|l|l|}
\hline Nr. & $\begin{array}{c}\text { Code/In-text } \\
\text { abbreviations }\end{array}$ & Age & Gender & $\begin{array}{l}\text { Residence } \\
\text { urban/rural }\end{array}$ & County \\
\hline 1 & CB & 22 & female & urban & Timiș \\
\hline 2 & AB & 22 & male & rural & Sibiu \\
\hline 3 & BA & 22 & male & urban & Timiș \\
\hline 4 & AB & 19 & female & urban & Gorj \\
\hline 5 & BG & 21 & female & rural & Timiș \\
\hline 6 & RB & 21 & male & rural & Hunedoara \\
\hline 7 & MP & 20 & female & urban & Timiș \\
\hline 8 & TL & 46 & female & rural & Maramureș \\
\hline 9 & AC & 20 & male & urban & Hunedoara \\
\hline 10 & RT & 21 & female & rural & Timiș \\
\hline 11 & MS & 21 & female & rural & Timiș \\
\hline 12 & IC & 21 & female & urban & Timiș \\
\hline 13 & MV & 25 & male & urban & Timiș \\
\hline 14 & IV & 27 & male & rural & Caraș Severin \\
\hline 15 & CGD & 38 & male & rural & Arad \\
\hline
\end{tabular}

Source: based on authors' own data interpretation gathered from the interviewees

ternative to the face-to-face and telephone interviews, especially when time, financial constraints, or geographical boundaries are barriers to an investigation (p. 1293). Students were easy to be selected : they are Romanian speaking geography students in their second and third year of study, and their email address are easy to be found in the listserv of WUT. They have some age between categories of interviewees (gender and age) and the dropout rate was zero, as no one dropped out during data collection. Overall response rate was $90 \%$. Data was analyzed thematically and discursively (Bryman, 2006; Mullet, 2019), and cross-referenced to the analysis of journalistic content outlined above to find common areas.

\section{Results}

Spatial distribution of votes for AUR at the 2020 Romanian Parliamentary elections

Post-communist Romanian electoral politics has been characterized by constant changes in the governing party or coalition. Support for particular parties has proven especially volatile since Romania joined the EU in 2007 (Giugăl et al., 2011). The December 2020 election was no exception, with power passing from the left-wing PSD to a more centre- right PNL-USRPLUS coalition. As previously mentioned, data from the Central Electoral Bureau (BEC, 2020) suggests an exceptionally low turnout, with only $33.3 \%$ of the eligible population voting. Turnout was highest in the south (Figure 1), which traditionally supports the left, peaking at $42 \%$ in Mehedinti county, and in Transylvania, where the Hungarian minority population votes faithfully for the Democratic Alliance of Hungarians in Romania, or UDMR, (turnout was 36\% in Harghita). Eastern counties that have previously been notable for high turnouts were surprisingly low, un- 
der $30 \%$. The total turnout in the capital, Bucharest, (in the south-east) was $30.07 \%$.

The results by party show that the PSD (Social Democrat Party) received the greatest share of the vote at $29 \%$, followed by the PNL (National Liberal Party) at 25.5\%. The USR-PLUS Alliance (Social Democrat Union-PLUS Alliance) came third at $15.8 \%$, and the AUR fourth, at $9.10 \%$. The UDMR scored 5.7\%, the PMP (People's Movement Party) 4.8\%, and PRO-Romania $4.10 \%$. A spatial map of regional vote distribution suggests that this followed conventional electoral tendencies (Figure 3), with a strong east-west/social democrat-liberal divide that correlates with socioeconomics (the east is generally poorer and less developed).

At a county level (Figure 4) the left-wing USR-Plus alliance won in two wealthier and more developed counties, Timis and Brasov, as well as in the capital city, Bucharest. The UDMR were predictably victorious in areas with a strong ethnic minority vote (Harghita, Covasna, Mures, Satu Mare). The only exception to the established patterns was in Vrancea: here, the liberal PNL were victorious over the PSD for the first time in 30 years. However, breaking down these results shows telling differences between the wealthier, more educated residents of urban areas, who voted PNL and USR-Plus, and the population from rural areas and smaller towns (Figure 5) who voted PSD.

The AUR vote looks remarkably consistent across both regions and counties, with distinct support from the eastern part of the country, but also from Arad and Hunedoara and Alba counties in the west (Figure 6). This shows that AUR support does have a strong spatial correlation with either wealth or deprivation. This bears out the work of Romanian sociologist $\mathrm{Du}$ mitru Sandu, who has argued that AUR support is highest in areas of intermediate socio-economic status, and is often strongest in communities that are situated at significant distances from major cities (San$\mathrm{du}, 2020)$. More finely grained analysis of BEC data bears this out: in 'intermediate' socio-economic areas more than $9 \%$ of the population voted AUR (BEC, 2020). However, our spatial map suggests that AUR received a significant share of the vote even in wealthy cities: $53 \%$ of AUR voters come from urban/city and small town areas. This contrasts sharply to the figures for the USR-PLUS, which has a highly urban electorate $(73 \%)$.

National level demographic analysis of the election data suggests that AUR supporters tend to be younger: $40 \%$ of those aged $18-35$ voted AUR. Within that $40 \%$ figure, $60 \%$ of the young people voting AUR were men (BEC, 2020). The only party to poll higher amongst 18-35 year olds was the left-wing USR-PLUS (45\%). This suggests a very different electorate for AUR than for its predecessor, the Greater Romania Party (PRM),

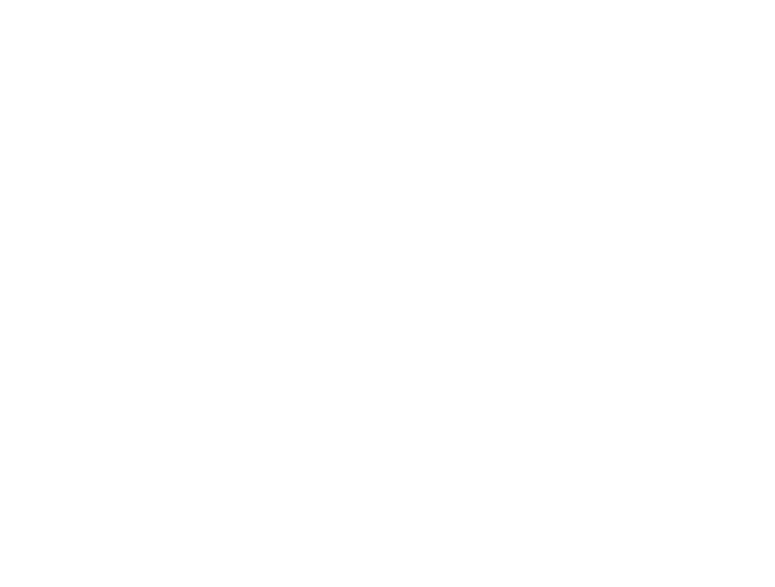

Figure 1. Turnout at the Romanian parliamentary election, December 2020, by county Data source: $B E C, 2020$ [click on figure to enlarge]

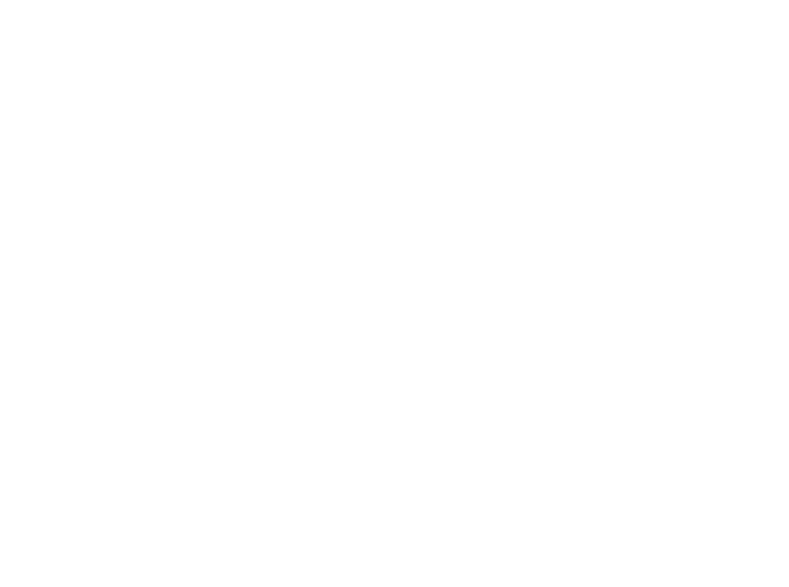

Figure 2. The winning parties in the historical regions of Romania, Romanian parliamentary elections, December 2020

Data source: $B E C, 2020$

[click on figure to enlarge]

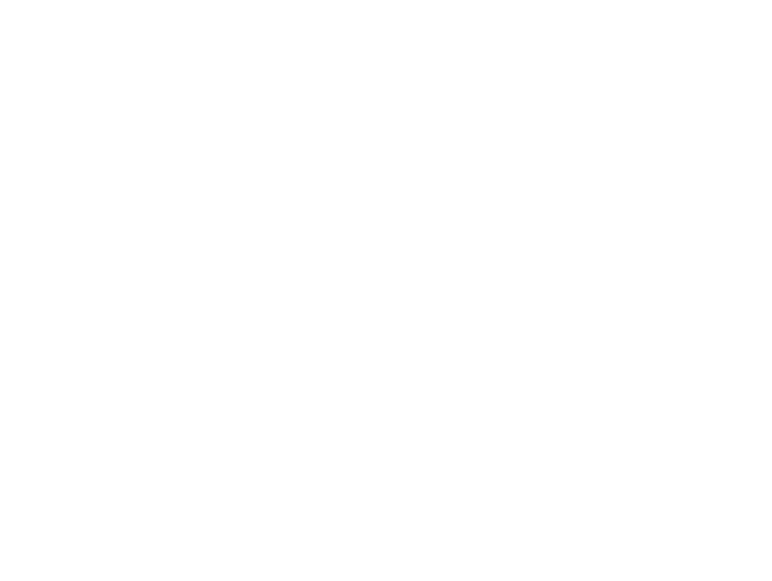

Figure 3. Vote share for the main parties in the historical regions of Romania, Romanian parliamentary elections,

December 2020

Data source: BEC, 2020

[click on figure to enlarge] 


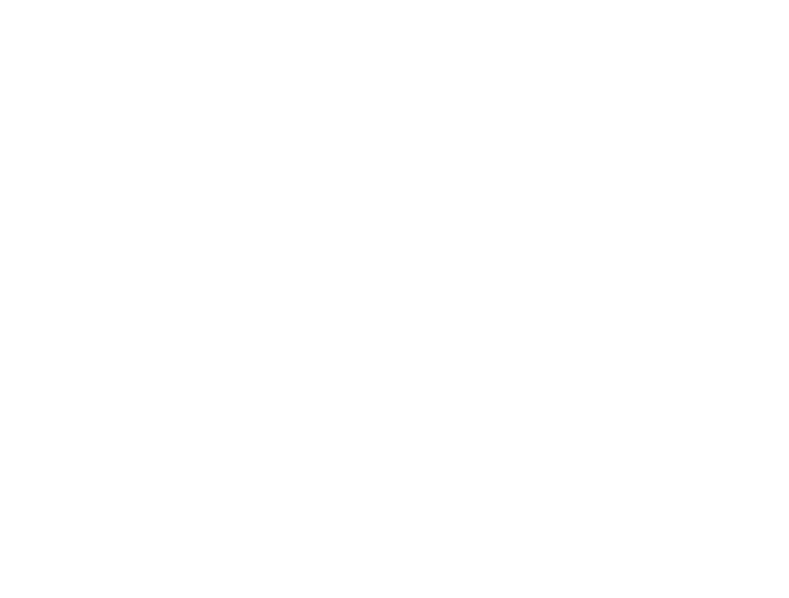

Figure 4. Winning parties by county, Romanian parliamentary elections, December 2020 Data source: BEC, 2020

[click on figure to enlarge]

which tended to draw support from older people who were nostalgic for communism (Badea, 2020).

Educationally, only $8 \%$ of all AUR voters have a university or further education degree, in comparison to $37 \%$ of voters for USR-PLUS. In short, the archetypal AUR voter is male, young, educated to an elementary or high school level, and lives in small town or rural area that is neither very deprived nor very wealthy (Badea, 2020).

\section{Secondary data analysis}

The success of AUR generated intense debates online. We identified five different influential interpretations in media that attempted to explain their success. Firstly, there were those who stressed the novelty of AUR, such as Ion Cristoiu, a prominent Romanian journalist, who considers their rise "the most spectacular event of the 30 years, following the change of regime in December 1989" (Cristoiu, 2020). For Cristoiu, it was the rhetorical shift from traditional policy areas to new themes such as corruption that attracted voters. By contrast, Gelu Duminică, a Roma sociologist, argues that the AUR won by ideological obfuscation, "through deceit, just as the fascist did in 1930," in particular the promulgation of xenophobic prejudice against minorities. However, Duminică is also critical of the failure of mainstream, traditional parties to speak to ordinary people at a time of crisis, and their tendency to priorities the needs of business (Hotnews, 2020). Similarly, Dumitru Sandu argues that the votes represent the disenfranchisement of the population from traditional politics, and widespread perception of government incompetence in the handling of COVID-19 (Sandu, 2020). By contrast, Duminicăs emphasis on fake news and conspiracy is shared by Cristian Pârvulescu, though where Cristoiu emphasizes novelty, Pârvulescu stresses continuity between

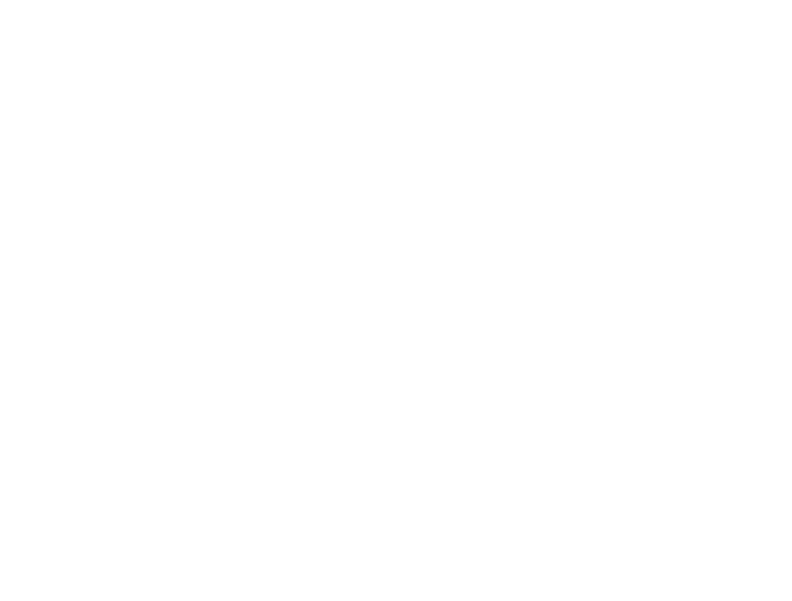

Figure 5. The results of the 2020 Parliamentary elections in Romania at the level of county capital municipalities Data source: $B E C, 2020$

[click on figure to enlarge]

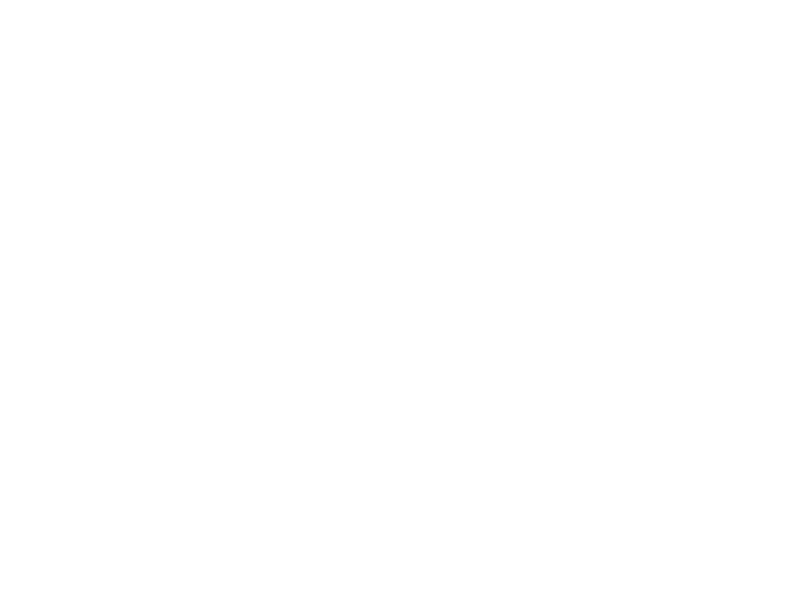

Figure 6. Proportion of AUR votes on counties Data source: $B E C, 2020$

[click on figure to enlarge]

the electorate for the AUR and previous supporters of the PRM, and the refusal of the PSD to capitalize on xenophobia (Matei, 2020). In contrast to these opinions, electoral data revealed that AUR took important shares of voters from PSD, especially from its more extremist voters (Badea, 2020).

Finally, relations with minorities in Romanian society play an important part in these debates. Some strands of media discourse emphasized the importance of Roma leaders in garnering support for the AUR, and there is indeed some evidence that prominent members of the Roma community lobbied strongly for the party. It is not uncommon for politicians to endeavor to appeal to the Roma vote in the run-up to elections across Central-Eastern Europe (Crețan et al., 2020; Crețan et al., 2021; Méreiné-Berki et al., 2017; Méreiné-Berki et al., 2021). Duminică condemns this support, reminding the Roma community of their racialization and persecution at the hands of far right leaders, including the deportation (and sometimes 
murder) of 25,000 Roma to Transnistria under Marshal Antonescu during World War II (Iacob, 2020). His argument connects drives for racial purity (the desire for a pure "Romania, like the holy sun on the sky") and the creation of racial 'scapegoats' with periods of crisis, when people feel drawn to authoritarian leaders, nostalgia, and a retreat to so-called 'traditional' values. Effectively, he accuses AUR-voting Roma of being complicit with the same logic that has led to their own marginalization, though he acknowledges that modern targets of AUR's xenophobia range from the Hungarian minority to the European Union.

COVID-19 acts as an important context for all of these explanatory frameworks. The pandemic has provided the AUR with an opportunity to grandstand against the government, organizing protests in $\mathrm{Bu}-$ charest and in other Romanian cities against mask wearing that acted as a gateway to a set of populist and nationalist ideas, such as the suggestion that the pandemic is a fiction to conceal malign foreign intervention against Romanians. The leaders of the party shifted thus the focal point from public health to anti-establishment statements that purportedly reassert Christian values, Romanian identity, and national interest against the weakening influence of atheism, social liberalism, global capitalism, and foreign influence. These have become increasingly dominant features of political rhetoric in the country since the 2008 financial crisis, though evidence suggests that Romanian nationalism is also supported by the Romanian diaspora, the fifth largest group of immigrants in OECD countries. Mocanu (2021) has drawn attention to the influential role of everyday habits, such as cooking traditional food, keeping up with the Romanian news, or video calling with family members, in the creation of a "banal nationalism" amongst this group, which work in combination with social media to mobilize political support at a distance. The COVID-19 pandemic may have been particularly disruptive for the Romanian diaspora, who often represent low-skilled workers desperate for employment to sustain their families.

\section{Interview data}

Our interviews assessed (i) where participants had learned about AUR (ii) what they knew about AUR ideology (including major rhetorical themes) and (iii) what role participants thought social media had played in their success. The majority of participants stated they heard about the party in the online press. Only a qurter had heard of AUR on Facebook, one fifth from friends, and the others on YouTube, and one respondent from a combination of the press and Facebook.

It is not clear that respondents could place the AUR in the wider Romanian political landscape, or cite many of their policies. However, most respondents had some understanding of the AUR's ideology as a form of nationalism, though their understanding of this term was somewhat basic in the majority of cases. Most respondents linked AUR's nationalism to some positively perceived virtues, like patriotism, pride in national history, preservation of traditional values, and anti-globalization sentiment. They thought that it was necessary for a nationalistic party to exist in Romania, either for reasons of political balance, or because they supported nationalist arguments: 'there should be someone who is vocal for the family, the country, faith, and freedom,' argued one (BG, 21, female). Other students associated nationalism with placing a value on people rather than money (TL, 46, female) and with positive desire for leadership by the in-group, rather than by strangers (MS, 21 , female). One respondent thought that a nationalist party should exist in Romania, but that AUR were a poor representation of such ideas:

"Yes, a nationalist party should be present on the Romanian political scene, but not with these characters, because one can easily see they are just for show, they lack substance." (MV, 25, male)

A quarter of participants explicitly associated AUR's nationalism with negative political dimensions. For instance, one interviewee saw it in liberal terms as an anti-modern force, using language that draws on ideas of 'progress':

"No, because of the transition period, the change of government from one party to another, which didn't do much for the evolution of this country... a nationalist party would only hinder the processes of progress that the country always wasted." (CDG, 37 , male)

Others saw it as a force leading to hatred, homophobia, and discriminatory xenophobia:

"I am convinced that Romanians can preserve their essence and traditions living side by side with other nationalities, so nationalism is useless; it is not necessary to promote this party, especially when this involves actions that instigate to hatred and violence." (AB, 19, female).

The damage done to public discourse by misinformation was also a feature of responses:

"Nationalism can be used today to manipulate people who don't look for more sources of information on some subjects and who like charismatic leaders or opinion makers." (CDG, 37, male)

On this theme, another participant noted the AUR's highly visible participation in COVID-19 protests and illogical ideologies as a hallmark: 'They promote their ideas rather ostentatiously and fervently' (MV, 25, male). Several respondents were alert to the role of controversy in promoting the AUR's platform, and the fact that algorithms can favour strong 
and bold statements over more carefully reasoned arguments.

Only one third of respondents were able to give an account of AUR ideology in terms of the traditional party political ideological spectrum: one stated that it was new, conservative, anti-European, and pro-Russian political force (AB, 22, male). A female respondent stated that the AUR wanted the reunification of Romania and an end to corruption (TL, 46, female). These results suggest that their ideological program may play a secondary role to the behavior and discourse of members, their opportunistic opposition to particular government decisions, and their deliberate courting of controversy.

Most respondents had a positive attitude towards the use of social media for sending political messages, provided the messages were not annoying, distressing or fake:

"I think it is very efficient as social networks are very much used by the majority of the population, especially the young, who are not always active in politics" (IC, 21, female)

Many respondents saw rapid and wide dissemination "as a positive feature, though some noted difficulties of information verification as a problem (though one respondent seemed to place the same weight on this as on grammatical accuracy!)

Political messages may be promoted on social media, "as most people are increasingly finding their information on there, but most of the time they are exaggerated and use bad grammar" (AB, 19, female)

One respondent believed that such messages would particularly influence those who did not grow up with technology, despite the tensions between such a view and the youthful demographics of the AUR (CA, 20, male).

For others, the distinction was between those who possessed critical skills and those who were incapable of distinguishing fake news from real ( $\mathrm{AB}, 22$, male). Other interviewees perceptively offered the view that social media gave marginalized individuals the opportunity to express opinions and to interact directly with 'important' party members, perhaps creating a sense of openness and belonging:

One can see them live on TV and social media at any hour, at any place, and due to the algorithms used by the social networks, even discussion forums were created by them. People on social media like to have an opinion and they can express themselves and even get in contact with party members, they feel important. They create a small virtual universe in which they feel important (CDG, 37, male).

It is possible that this lends AUR politicians an availability and a connection with ordinary people that more conventional politicians appear to lack, helping to forge an image of them as the party of the people.

Surprisingly, however, most of the respondents admitted to having seen messages from AUR on social media. They had not encountered these or could not remember if they had or not. Those who saw AUR messages recalled them being about the main themes supported by the party, such as traditional family values ( $\mathrm{AB}, 22$, male) and corruption (TL, 46, female), as well as their position against COVID-19 restrictions and the LGBT community (AB, 19, female). Many participants noted that the presentation made their messaging difficult to ignore, again emphasizing style over content:

"The majority of the methods they use to gain publicity are ostentatious, even people who are not interested in politics already have an image of AUR, and even if you disagree with what they say, you cannot ignore how spectacularly they present themselves, even if the way in which they do it resembles a circus act which people forget about the next moment" (MV, 25, male)

However, less than a half of participants stated that they did not find such actions interesting, or were unaware of them. Even where participants identified a theme of AUR discourse as important, they tended to distance themselves from the party:

"The most interesting activity is the attempt to reunify Romania with Moldova, but I believe the way in which they are trying to do this is appalling" ( $A B$, 19 , female)

Participants further also asked asked their feelings on specific AUR party policies. The AUR campaign against pandemic restrictions proved a particularly divisive issue. More than half of the participants were against the AUR stance related to the COVID-19 restrictions:

- "It is a nationalist party involved in anti-restrictions and anti-COVID protests and has members with illogical ideologies" (CA, 20, male)

- "People believed their false allegations and voted for them because they were anti -vaccines or antiCOVID-19 or anti-Europe" (AB, 22, male)

This reflects wider social trends, with the younger Romanian generations (and the very religious) more suspicious of vaccination than older people.

COVID-19 was a fertile ground for AUR to launch counter-actions against the Romanian Government restrictions. There were many protests organized by different party members in numerous cities in Romania in 2020-2021. 'Mask down!' and 'No to the vaccine!' were among their major slogans. They used to wear masks made by plastic even in the Parliament, just as a form of resistance to Government rules. 
A majority of interviewees felt that the unification of Romania and the Republic of Moldova was impossible to accomplish in practice, and hence considered it a rhetorical 'trick' by the party to rouse public feeling by touching a sensitive chord. However, some argued that unification was long overdue (RB, 21, male) or that it would be welcomed by the people of Moldova (BG, 21, female). Others were aware that there is not currently much popular support for unification in Moldova, as recent elections and a referendum on the subject indicate (CDG, 37, male; $\mathrm{AB}, 22$, male).

Traditional Orthodox family values divided respondents. A quarter of interviewees supported the view that family should be a heterosexual unit:

- "Family was always formed by a man and a woman, what happens now can only upset God" (TL, 46, female)

- "The best idea is that marriage is between a man and a woman, not a woman and another woman, or a man and another man" (BG, 21, female)

Others took a more socially liberal view, and argued that homophobia helped to generate attention for the AUR, but was ultimately divisive in its impacts on the population (MV, 25, male; CDG, 37, male). Several participants argued that families should receive financial support and free time to raise children (BA, 22 , male).

Support for ethnic Romanians in majority Hungarian areas was not prioritized by respondents, possibly due to a lack of knowledge about the issues, since they affect a different area of the country. However, one participant did echo AUR rhetoric:

- "Romanians are harassed in the counties where Hungarians are the majority" (TL, 46, female)

However, other respondents understood that such a discourse could be used to manipulate voters:

- "Romanian communities in Transylvania and their cultural heritage will always be used as themes in electoral campaigns, but real ethnic problems in the Transylvanian region will never be fixed due to lack of interest" (CDG, 37, male).

The fight against the entry of foreign companies into the Romanian economy was controversial. Since Romania passed from communism to liberalism, the state has been eager to attract new foreign investment, particularly to revivify ageing infrastructure that requires new (Crețan et al, 2005). This has led to a degree of pressure on the government from foreign interests who are eager to invest to shape favourable policies to their needs. The AUR has successfully capitalized on the disquiet that this introduction of glob- al capital has created, using it to attract senior/elderly voters. Certainly, among the elderly generations who lived in communism there are some nostalgic people of communist industrialized spaces (Săgeată, Mitrică, \& Mocanu, 2021). Some participants supported the AUR's campaign, arguing that it would lead to the development of local businesses and generate beneficial development and economic growth as profits were reinvested locally or regionally rather than extracted to fund projects elsewhere (IC, 21, female; RT, 21, female). Many respondents believed that foreigners should not be allowed to head Romanian businesses or to own land in the country. However, a quarter of respondents underlined the importance of foreign help for the development of the country, arguing that Romania could not exist outside a globalized context as the economy would be dead without foreign investments. Other interviewees thought that business policies that discriminated against foreign companies would cause them to flee, generating economic problems.

All respondents considered the fight against the corruption of the political class as an idealistic pursuit, rather than a realizable goal. This cynicism perhaps indicates the long-lasting problem of corruption as a persistent feature of Romanian politics, during the post-communist era. Corruption undermined democratic consolidation in Romania (Ristei, 2010). Even if the post-communist Romanian political discourse has been dominated by the fight against government corruption, little has been done to solve this issue (Hein, 2015):

- "Corruption exists and I doubt that one party could do anything about it" (MV, 25, male)

- "Corruption will always exist, but fighting against it is a good idea" (CA, 20, male)

While one respondent argued that politicians were too readily accused of corruption by those not in power: 'First one party has to get to the power and then talk about fighting corruption' (CDG, 37, male), others argued that it remained an important ambition: 'I don't think that it is possible to eradicate corruption but a change in this direction would be welcome and implementing stronger measures against corruption would be some solution (IC, 21, female)

The AUR's anti-bear hunting campaign was stimulated by the shooting of 'Arthur', the largest bear in Romania, by Austrian Prince Emmanuel of Lichtenstein (whether or not this particular bear was the one shot, however, remains open to dispute). This issue brings together environmental concerns and an animal rights agenda with an older class politics. Habitat loss in Romania has led to a spate of bear attacks on people, as the 
human and ursine populations are brought into closer contact by deforestation. Animal rights have also become a heated area of debate post-communist Romania, with the killing of dogs (Crețan, 2015) and wild animals a particularly sensitive issue. Further, hunters are perceived by middle class Romanians as members of a privileged upper class, whose interests do not necessarily coincide with the rural classes who farm and manage land for a living (O’Brien \& Crețan, 2019).

In the aftermath of this particular shooting, the AUR took to the airwaves to protest, a stance supported by the majority of younger participants, many of whom took a wider ecological perspective or animal rights perspective on the matter:

- "This is very important as it would protect bears from extinction" (IC, 21, female)

- "I agree with this too. Bears were deprived of their habitats so they come in the cities and villages." (TL, 46, female)

- "I was very upset when I heard the news about the killing of Arthur the bear" (RT, 21, female)

However, other younger respondents were skeptical about whether the AUR had a real solution to the underlying problem of habitat destruction $(\mathrm{AB}, 22$, male), though one noted that the party was endeavouring to prevent the destruction of forests in the Carpathians (RB, 21, male). Others questioned the significance of the problem to the wider population: 'Trophy hunting is a very profitable business and this theme upsets some very select groups of people' (CDG, 37, male).

Summing up, AUR brings to the public sphere a mix of nationalism, religious faith, traditional family values and several ideological elements, such as antiglobalization, environmentalism, animal rights, and anti-government critique to create an 'alternative' political rhetoric. Our research bears out the contention that this mixture of issues relies on the productive ambiguity of a blended critique that offers a rhetoric of elite corruption intertwined with xenophobic and nationalist ideas (Table 2). In the fertile ground offered by the visible exertion of government powers with the enactment of COVID-19 restrictions, this mixture has proven persuasive to many Romanians, though our interviews suggest that it has limited appeal to more educated young people.

Table 2. Results summary

\begin{tabular}{|c|c|}
\hline \multicolumn{2}{|c|}{ RESULTS OF STATISTICAL ELECTORAL DATA INTERPRETATION } \\
\hline \multirow{4}{*}{ Statistical electoral data on AUR } & $\begin{array}{l}\text { AUR electorate rests more in Dobrogea/Dobruja and Moldova } \\
\text { regions }\end{array}$ \\
\hline & $\begin{array}{l}\text { Profile of AUR voter - up to } 35 \text { years old men with elementary and } \\
\text { high school education }\end{array}$ \\
\hline & $40 \%$ of AUR voters are younger people (under 35 ) \\
\hline & $8 \%$ of AUR voters are younger educated people \\
\hline \multicolumn{2}{|l|}{ RESULTS OF MEDIA DATA INTERPRETATION ON AUR } \\
\hline \multirow{5}{*}{ Opinion of major political analysts on AUR } & $\begin{array}{l}\text { Cristoiu lon: AUR comes with novelty in ideology bringing to the } \\
\text { forefront the issue of corruption }\end{array}$ \\
\hline & $\begin{array}{l}\text { Duminică Gelu: AUR has ideological obsfucation (e.g. the } \\
\text { promulgation of xenophobic prejudice against minorities) }\end{array}$ \\
\hline & $\begin{array}{l}\text { Sandu Dumitru: votes for AUR came as disenfranchisement of the } \\
\text { population from traditional politics and the COVID-19 restrictions }\end{array}$ \\
\hline & $\begin{array}{l}\text { Pîrvulescu Cristian: nationalist continuity and relation with the PRM } \\
\text { (Greater Romania Party) }\end{array}$ \\
\hline & $\begin{array}{l}\text { Duminică Gelu: the importance of AUR relation to minorities (e.g. } \\
\text { Roma leaders garnered support in elections for the AUR) }\end{array}$ \\
\hline The COVID-19 context for mobilizing support for AUR & $\begin{array}{l}\text { The COVID-19 has provided the AUR with an opportunity to } \\
\text { grandstand against the government, organizing protests }\end{array}$ \\
\hline
\end{tabular}




\begin{tabular}{|c|c|c|c|c|}
\hline \multicolumn{3}{|c|}{ RESULTS OF INTERVIEW DATA INTERPRETATION } & $\begin{array}{l}\text { Number of } \\
\text { respondents }\end{array}$ & $\%$ \\
\hline \multirow{5}{*}{\multicolumn{2}{|c|}{ Perceived AUR political discourse }} & Appropriate & 1 & 6.67 \\
\hline & & Homophobic and Xenophobic & 4 & 26.67 \\
\hline & & Violent & 3 & 20 \\
\hline & & Anti-European and Pro-Russian & 2 & 13.33 \\
\hline & & $\begin{array}{l}\text { Manipulative of information/ promoter of } \\
\text { fake news }\end{array}$ & 5 & 33.33 \\
\hline \multirow{5}{*}{\multicolumn{2}{|c|}{ Use of social media for sending political messages }} & Approved & 11 & 73 \\
\hline & & Disapproved & - & - \\
\hline & & Ambivalent & 3 & 20 \\
\hline & & Not know & 1 & 6.67 \\
\hline & & No response & - & - \\
\hline \multirow{35}{*}{ 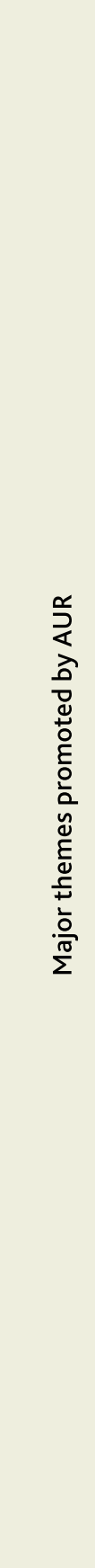 } & \multirow{5}{*}{$\begin{array}{l}\text { Anti-pandemic and COVID-19 restrictions } \\
\text { stand }\end{array}$} & Approved & 5 & 33.33 \\
\hline & & Disapproved & 5 & 33.33 \\
\hline & & Ambivalent & 2 & 13.33 \\
\hline & & Not know & 2 & 13.33 \\
\hline & & No response & 1 & 6.67 \\
\hline & \multirow{5}{*}{$\begin{array}{l}\text { Unification of Romania and the } \\
\text { Republic of Moldova }\end{array}$} & Approved & 9 & 60 \\
\hline & & Disapproved & 3 & 20 \\
\hline & & Ambivalent position & 1 & 6.67 \\
\hline & & Not know & 1 & 6.67 \\
\hline & & No response & 1 & 6.67 \\
\hline & \multirow{5}{*}{ Traditional Orthodox family values } & Approved & 8 & 53.33 \\
\hline & & Disapproved & 6 & 40 \\
\hline & & Ambivalent position & - & - \\
\hline & & Not know & 1 & 6.67 \\
\hline & & No response & 1 & 6.67 \\
\hline & \multirow{5}{*}{$\begin{array}{l}\text { Support for ethnic Romanians in regions } \\
\text { inhabited in majority by ethnic Hungarians }\end{array}$} & Approved & 5 & 33.33 \\
\hline & & Disapproved & 4 & 26.67 \\
\hline & & Ambivalent position & 2 & 13.33 \\
\hline & & Not know & 2 & 13.33 \\
\hline & & No response & 2 & 13.33 \\
\hline & \multirow{5}{*}{$\begin{array}{l}\text { Fight against foreign corporations in } \\
\text { Romania }\end{array}$} & Approved & 8 & 53.33 \\
\hline & & Disapproved & 5 & 33.33 \\
\hline & & Ambivalent & - & - \\
\hline & & Not know & 1 & 6.67 \\
\hline & & No response & 1 & 6.67 \\
\hline & \multirow{5}{*}{ Fight against corruption of politicians } & Approved & 7 & 46.67 \\
\hline & & Disapproved & 3 & 20 \\
\hline & & Ambivalent position & 2 & 13.33 \\
\hline & & Not know & 1 & 6.67 \\
\hline & & No response & 2 & 13.33 \\
\hline & \multirow{5}{*}{ Environmental/animal right issues } & Approved & 12 & 80 \\
\hline & & Disapproved & 1 & 6.67 \\
\hline & & Ambivalent position & 1 & 6.67 \\
\hline & & Not know & - & - \\
\hline & & No response & 1 & 6.67 \\
\hline
\end{tabular}

Source: based on authors' own data interpretation based on national electoral data, media sources and interview data 


\section{Conclusions}

This paper suggests that the COVID-19 pandemic has forced the exertion of power by the government to the highly visible forefront of everyday life, which has played an important role in creating discursive space for the rise of nationalist parties. Pandemic restrictions have thus provided an ideal opportunity for the AUR to take a series of 'non-mainstream' oppositional stances, to stoke controversy, and to capitalize on decreasing social trust in the state.

In terms of the content of AUR policies, our research confirms the analysis of Ben Stanley, who argues that populism is a 'thin' political ideology, which seeks to make opportunistic use of a more broader and established right wing ideological repertoire (Stanley, 2008). Our findings also confirm Brubaker's contention that populism mixes a critique of elites with a xenophobic antipathy to those who are outside of the nation, sliding between these two registers across a series of issues. Yet there is a mixture of older and newer ideologies in play, as populist parties reinvent far right agendas to respond (often opportunistically) to issues of the present. The Romanian experience of the COVID-19 pandemic has provided an ideal opportunity for the AUR to harness old political antagonisms (nationalism, ideas of the 'fatherland', the reunification of territory, xenophobia, homophobia, a defence of 'traditional values', religious faith, and nostalgia for communism) to newer causes (environmentalism, anti-globalization, anti-public health restrictions), which may help to explain its appeal to younger voters. While our research found that educated young Romanians were not particularly favourable to the AUR, many did express some degree of agreement with elements of their ideological stances.

Like many other populist parties, the style of AUR's campaigning is also innovative. They pursue deliberately controversial lines of attack, seeking visibility to the point of relying on stunt-like spectacle at times and making use of new technologies to disseminate their messages (social media, mobile phone video). Our research suggests that educated young Romanians did not find these techniques persuasive, and were alerted by the style of politics to the potential for 'fake news' and misrepresentation in the content.

Our findings suggest that there are commonalities between the rise of the AUR and the style of illiberal conservatism promoted by Viktor Orbán in Hungary. In fact, the politics of some parties in Central and Eastern Europe is arguably characterized at the present time by the challenge presented to liberal democracy by these forces. While many educated younger people are aware of the ideological thinness of the AUR's politics and the multiple layers of misrepresentation in their messaging, the popularity of the party is nonetheless rising amongst younger demographics, and those who are unhappy with the current political, social, and economic configuration. The combination of an anti-elite ideology with strong xenophobic nationalism is clearly a potent one, particularly in more rural areas and small towns, and especially at times of crisis. More follow-up research is urgently required to chart the future of the AUR and its changing ideological commitments, but we hope that this article will sound an alarm amongst readers that this is not simply an old threat in new clothes, but a reinvented and potentially vigorous reworking of nationalist ideology.

\section{Acknowledgements}

We would like to thank the two anonymous reviewers for their feedback on the previous version of this paper.

\section{References}

Albertazzi, D., \& McDonnell, D. (Eds.) (2008). Twentyfirst century populism: the spectre of Western European democracy. Basingstoke: Palgrave Macmillan

Badea, C. (2020). Care e profilul votanților partidelor câștigătoare și cum a reușit AUR marea surpriză, Spotmedia.ro, 9 December 2020 [What is the profile of the voters of the winning parties and how did AUR manage the big surprise]. https://spotmedia.ro/stiri/alegeri-parlamentare-2020/ alegeri-parlamentare-2020-care-e-profilul-votantilor-partidelor-castigatoare-si-cum-a-reusit-aurmarea-surpriza-electorala-interviu-cu-sociologul-dan-jurcan (12.10. 2021)

BEC. (2020). Data on the 2020 Parliamentary Elections in Romania. https://parlamentare2020.bec.ro/ (06.2021)

Betz, H. G. (2002). Conditions favouring the success and failure of radical right-wing populist parties in 
contemporary democracies. In: Mény, Y., \& Surel, Y. (Eds.), Democracies and the Populist Challenge (pp. 197-213). New York: Palgrave

Billig, M. (1995). Banal nationalism.Thousand Oaks, CA: Sage

Bos, L, van der Brug, W, \& de Vreese, C.H. (2013). An experimental test of the impact of style and rhetoric on the perception of right-wing populist and mainstream party leaders. Acta Politica, 48(2), 192-208

Brubaker, R. (2017). Why populism? Theory and Society, 46, 357-385. DOI: 10.1007/s11186-017-9301-7

Brubaker, R. (2020a). Populism and nationalism. $\mathrm{Na}$ tions and Nationalism 26(1), 44-66. DOI:10.1111/ nana.12522

Brubaker, R. (2020b), Paradoxes of populism during the pandemic, Thesis Eleven. (in press) DOI: 10.1177/0725513620970804

Bryman, A. (2016). Social research methods, 5th ed. Oxford University Press: Oxford, UK.

Carter, E. (2005). The extreme right in Western Europe: success or failure? Manchester: Manchester University Press.

Chapman, K. (2021). Critique of conspiracy: how do we tell the difference?. Planning Theory and Practice, 22(1),128-132

Crețan, R., Guran-Nica, L., Platon, D., \& Turnock, D. (2005). Foreign direct investment and social risk in Romania: progress in Less-favoured areas. In: Turnock, D. (Ed.). Foreign Direct Investment and Regional Development in East Central Europe and the Former Soviet Union (pp. 305-348). Routledge: London. DOI: 10.4324/9781351158121-15.

Crețan, R. (2015). Mapping protests against dog culling in post-communist Romania, Area, 47(2), 155 165. DOI: $10.1111 /$ AREA.12155

Crețan, R., Covaci, R., \& Jucu, I. S. (2021). Articulating 'otherness' within multiethnic rural neighbourhoods: encounters between Roma and non-Roma in an East-Central European borderland. Identities: Global Studies in Culture and Power. (in press) DOI : 10.1080/1070289X.2021.1920774

Crețan R, Málovics, G., \& Méreiné-Berki, B. (2020). On the perpetuation and contestation of racial stigma : urban Roma in a disadvantaged neighbourhood of Szeged. Geographica Pannonica, 24(4), 294 310. DOI: $10.5937 / G P 24-28226$

Cristoiu, I. (2020). Învinși și învingători în Pandemie. Azi: AUR a produs una dintre cele mai mari surprize postdecembriste [Losers and winners during the pandemic. Today AUR produced one of the biggest post-December 1989 surprises]. Cristoiublog. Available at https://www.cristoiublog.ro/2020-invinsi-si-invingatori-in-pandemie-azi-aur-a-produs-una-dintre-cele-mai-mari-surprize-postdecembriste/ (20.07.2020)
Curierul Național, (2020). AUR cere urgentarea inscrierii Rosiei Montane in UNESCO [AUR demands the urgency of registration of Rosia Montana in the UNESCO]. https://curierulnational.ro/a-u-r-cereurgentarea-inscrierii-rosiei-montane-in-unescoproteste-masive-in-cazul-in-care-guvernul-orbannu-isi-respecta-promisiunile/ (10.10.2021).

De Cleen, B., \& Stavrakakis, Y. (2017). Distinctions and articulations: a discourse theoretical framework for the study of populism and nationalism. Javnost-The Public, 24(4), 301-319. DOI: 10.1080/13183222.2017.1330083

Despa, O., \& Albu, I. (2021). In Eco-chambers'of nationalist Romanian party, Rusia's favourite narratives, Balkaninsight. https://balkaninsight. com/2021/10/08/in-echo-chambers-of-nationalist-romanian-party-russias-favourite-narratives/ (15.10.2021)

Gava, I.-R. (2021). AUR, reactie la petitia societatii civile adresata coalitiei de guvernare: Va amintim noi ce inseamna democratia [AUR, reaction to the petition addressed by the civil society to the governing coalition: We will remind you what democracy means]. DC News. https://www.dcnews. ro/alianta-pentru-unirea-romanilor-reactie-lapetitia-societatii-civile-adresata-coalitiei-de-guvernare-va-amintim-noi-ce-inseamna-democratia 799686.html (10.02.2021)

Gherghina, S., \& Mișcoiu, S. (2014). A rising populist star: The emergence and development of the PPDD in Romania. Debatte: Journal of Contemporary Central and Eastern Europe, 22(2), 181-197

Gherghina, S., Mișcoiu S., \& Soare, S. (2013). Contemporary populism: a controversial concept and its diverse forms. Cambridge Scholars: London

Giugăl, A., Johnston, \& Constantinescu, S. (2011). Democratic Musical Chairs? Romania's Post-1989 Electoral Geography. Space and Polity, 15(2), 143161 DOI: 10.1080/13562576.2011.625224

Hein, M. (2015). The fight against Government corruption in Romania: irreversable results pr Sysyphean challenge? Europe-Asia Studies, 67(5), 747-776. DOI: $10.1080 / 09668136.2015 .1045834$

Hotnews. (2020). "Fenomenul partidului AUR si o radiografie a societatii romanesti dupa alegerile parlamentare. Sociologul Duminică: Romania reala s-a simtit abandonata de partidele mari" [The AUR party phenomena and a radiography of the Romanian society after the parliamentary elections. The Sociologist Duminică: Real Romania felt abandoned by the big parties]. Hotnews. https://www.hotnews.ro/ stiri-esential-24467680-fenomenul-partidului-aurradiografie-societatii-romanesti-dupa-alegerile-parlamentare-sociologul-gelu-duminica-romania-realasimtit-abandonata-partidele-mari.htm (25.04.2021). 
Iacob, V., (2020). Gelu Duminică, despre romii care au lucrat electoral pentru AUR: $\mathrm{Nu}$ vor mai colabora cu mine sau cu functia pe care o reprezint [Gelu Duminica about the Rroma who campaigned for AUR: They will no longer collaborate with me or the function I represent]. Ziare.com. https://ziare.com/stiri/eveniment/gelu-duminica-despreromii-care-colaborat-electoral-cu-aur-1649304 (25.04.2021.)

Ignazi, P. (2003). Extreme Right Parties in Western Europe. Oxford: Oxford University Press

Kriesi, H. (2014). The populist challenge. West European Politics, 37(2), 361-378

Laclau, E. (2005). On Populist Reason. London: Verso

Lucheș, D., Saghin, D., \& Lupchian, M. M. (2021). Public perception of the first major SARS-Cov-2 outbreak in the Suceava county, Romania. International Journal of Environmental Research and Public Health, 18(4). 1-21. DOI: https://doi.org/10.3390/ ijerph18041406

Matei, C. (2020). "Gazetarul Cristian Tudor Popescu: AUR își are originile în Partidul Comunist” [The Journalist Cristian Tudor Popescu considers that AUR has its origins in the Communist Party]. Stirile PROTV. Available at https://stirileprotv.ro/stiri/ politic/gazetarul-cristian-tudor-popescu-aur-isiare-originile-in-partidul-comunist.html $\quad(05.02$ 2021)

Matei, E., Ilovan, O.R., Sandu, C. B., Dumitrache, L., Istrate, M., Jucu, I.S., \& Gavrilidis, A. A. (2021). Early COVID-19 pandemic impacts on society and environment in Romania. Perception among population with higher education. Environmental Engineering and Management Journal, 20(2), 319-330.

Meho, I. L., (2006). E-Mail Interviewing in Qualitative Research: A Methodological Discussion. Journal of the American Society for Information Science and Technology, 57(10), 1284-1295. DOI: 10.1002/ asi. 20416

Méreiné-Berki, B., Málovics, G., Crețan, R., \& Toth, J. (2017). The role of social capital and interpersonal relations in the alleviation of extreme poverty and spatial segregation of Romani People in Szeged. Journal of Urban and Regional Analysis, 9(1), 33-50. DOI: 10.37043/jura.2017.9.1.2.

Méreiné-Berki, B., Málovics, G., \& Crețan, R. (2021). "You Become One with the Place": Social Mixing, Social Capital, and the Lived Experience of Urban Desegregation in the Roma Community. Cities, 117. DOI: 10.1016/J.CITIES.2021.103302.

Mocanu, I. (2021). Nationalism versus globalization in times of Coronavirus. On cultural intimacy and long distance Coronationalism. Or why Romanian diaspora voted for the extreme right, Available at https://nationalism.ceu.edu/sites/nationalism. ceu.hu/files/attachment/basicpage/422/mocanuirinanatessaycomp.pdf. (15.08.2021).

Mudde, C. (2004). The populist zeitgeist. Government and Opposition, 39(4), 542-563

Mudde, C., \& Kaltwasser, C. R. (2013). Exclusionary vs. inclusionary populism: comparing contemporary Europe and Latin America. Government and Opposition 48(2), 147-174

Mullet, D. R. (2018). A general critical discourse analysis framework for educational research. Journal of Advanced Academics, 29(2), 116-142. DOI: 10.1177/1932202X18758260

O'Brien, T., \& Crețan, R. (2019). The role of identity in the 2015 Romanian shepherd protests. Identities: Global Journal of Culture and Power 26(4), 470-488. DOI: $10.1080 / 1070289 X .2017 .1400322$

Orenstein, A. M., \& Bugaric, B. (2020). Work, family, Fatherland: the political economy of populism in Central and Eastern Europe. Journal of European Public Policy. (in press) DOI: 10.1080/13501763.2020.1832557

Partidul AUR (2021a). Website of Partidul AUR. Available at www.partidulaur.ro (06.06.2021)

Partidul AUR (2021b). "Alianta pentru Unirea Romanilor contesta la Curtea de Apelrestrictiileimpuse de Guvern sub pretextulcombateriipandemiei" [The Alliance for the Union of Romanians challenge at the Appeal House the restrictions imposed by the Government under the pretext of the fight against the pandemic]. PartidulAUR. Available at https://partidulaur.ro/alianta-pentru-unirea-romanilor-contesta-la-curtea-de-apel-restrictiile-impuse-de-guvernsub-pretextul-combaterii-pandemiei/ (06.05.2021).

Partidul AUR. (2021c). "Comunicat de presa: Romanii au scos din buzunarpeste 170 de milioane de euro pentru a platiamenzineconstitutionale" [Press release: Romanians pulled out of their pockets more than 170 million Euro to pay for unconstitutional fines]. Agerpress. 2021. Available at https:// www.agerpres.ro/comunicate/2021/05/27/comunicat-de-presa-alianta-pentru-unirea-romaniloraur--720804 (30.05.2021).

Partidul AUR. (2021d). Pietrele vor striga in Secuime [Stones will shout in the Szeklarland]. Available at https://partidulaur.ro/pietrele vor_striga $n$ secuime/ (15.02.2021)

Partidul AUR. (2021e). UDMR isi vrea orasele inapoi [UDMR wants its towns back]. Available at https://partidulaur.ro/UDMR i vrea napoi marile ora e/ (15.02.2021).

Pirro, A. (2015). The populist radical right in Central and Eastern Europe: ideology, impact, and electoral performance. London: Routledge

Pîrvu, L. (2021). Marele câștigător al crizei politice de la București. Cât de mult contează saltul AUR în 
sondaje și ce relevanță are pe viitor [The hreat winner of political crises from Bucharest. How much does the AUR jump in polls matter and how relevant is it in the future], Hotnews. Available at https:// www.hotnews.ro/stiri-politic-25093003-marelecastigator-crizei-politice-bucuresti-cat-mult-conteaza-saltul-aur-sondaje-relevanta-are-viitor.htm (14.11.2021).

Popa, N., Pop, A.-M., Marian-Potra, A. C., Cocean, P., Hognogi, G. G., \& David, N. A. (2021). The Impact of the COVID-19 pandemic on independent creative activities in two large cities in Romania. International Journal of Environmental Research and Public Health, 18(14), 7674. DOI: 10.3390/ijerph18147674

Popescu, D. (2020). Interzicerea pelerinajului la Sf. Paraschieva pentru credinciosii din afara Iasului este disproportionate si discriminatorie [Interdiction of pilgrimage to Saint Parascheva for people who are not resident in Iasi is disproportionate and discriminatory decission]. Available at https://www.agerpres.ro/culte/2020/10/09/patriarhul-daniel-interzicerea-pelerinajului-la-sf-cuvparascheva-pentru-credinciosii-din-afara-iasiu$\underline{\text { lui-disproportionata-si-discriminatorie--588544 }}$ (04.01.2021).

Rădulescu, M. (2021). "Ce poate face România în fața coronavirus și ce are de făcut în viitor" [What can Romania do against the corona virus and what should it do in the future]. Partidul AUR. Available at https://partidulaur.ro/ce-poate-face-romania-in-fata-coronavirus-si-ce-are-de-facut-in-viitor/ (17.02.2021).

Ristei, M. (2010). The politics of corruption: political will and the rule of law in post-communist Romania. Journal of Communist Studies and Transition Politics, 26(3), 341-362

Rîșteiu Toader, N., Crețan, R, \& O’Brien, T. (2021). Contesting post-communist development: gold extraction, local community, and rural decline, Eura- sian Geography and Economics. DOI: 10.1080/1538 7216.2021 .1913205 (in press)

Sandu, D. (2020). "Contextul de votare la parlamentarele din 2020 " "The context of the parliamentary ellections of 2020]. Contrubutors. Available at https:// www.contributors.ro/contextul-de-votare-la-parlamentarele-din-2020/ (Accessed 27.12.2020).

Săgeată R., Mitrică, B., \& Mocanu, I. (2021). Centralized industrialization in the memory of places. Case studies of Romanian cities. Societies, 11, 1-16. DOI: $10.3390 /$ soc11040132

Simion, G. (2021). "Romania exporta pe nimic grau si primeste paine congelata de trei ori mai scumpa" [Romania exports wheat almost for free and imports frozen bread thrice more expensive]. George Simion. Available at https:// www.facebook.com/george.simion.unire/photos la.2212856872268804/3069430123278137/ (06.06 2021).

Stanley, B. (2008). The thin ideology of populism. Journal of Political Ideologies, 13(1), 95-110

Stroschein, S.l. (2019). Populism, nationalism, and party politics. Nationalities Papers, 47(6), 923-935

Taggart, P. (2000). Populism. Buckingham: Open University Press

Vesalon, L., \& Crețan, R. (2013). Mono-industrialism and the struggle for alternative development: the case of the Rosia Montana project, Tijdschrift voor economische en social geografie, 104(5), 539-555. DOI: 10.1111/TESG.12035

Voicu, O. (2021). Apel catre liderii coalitiei de guvernare sa inceteze contactul cu AUR [Appeal to the leaders of the governing coalition to cease any contact with AUR]. PS News. https://psnews.ro/ apel-catre-liderii-coalitiei-de-guvernare-sa-inceteze-contactul-cu-aur-490632/ (06.02.2021).

Voiculescu, S., \& Groza, O. (2021). Legislating political space for LGBT families: The 2018 referendum on the definition of family in Romania, Area. (in press). DOI 10.1111/area.12729 